\title{
LOGISTIC QUESTIONS AND SOLUTIONS AT A SPECIAL SLAUGHTER COMPANY, BECK-HÚS LTD.
}

Edina Lendvai

University of Szeged, Faculty of Engineering 6724 Szeged, Mars tér 7.

e-mail: lendvai@mk.u-szeged.hu

\begin{abstract}
In our work, we analysed the most logistic problem of the meat production and distribution. To reach our aims, we made an interview with the manager of a meat small enterprise. There are 2 main activities, the cutting is in Csávoly (little village, near the Baja), and the producing is in Baja. We asked the manager about these main activities, their capacity, the most important products. We have got a lot of information about their partners, the terms of payments, and the main problems. We tried to make a proposal and give some advice to develop the factory.
\end{abstract}

Keywords: Logistic, Meat Production, Meat Distribution

\section{INTRODUCTION}

Logistic is management approach directed to planning, regulation, realization of the flow - basically materials (raw materials, semi-finished and finished products), energy, information and persons - in different systems or into them, and its aim is to reach the optimal cost of process and customer service level [1].

In other words, the notion of so-called 5R (7R, 9R) is the best known means:

Materials / products and information needed for the smooth operation of the company are required:

- in the Right Goods,

- $\quad$ in Right quantity,

- in Right place,

- at the Right time,

- at a Right price [2].

Logistics' corporate tasks include the following major activities:

- supply,

- production,

- distribution,

- $\quad$ and waste management [3].

Within these, of course, countless tasks to be solved as, e.g., in case of production: purchase, sales, internal delivery routes, conducting major information and material flows related to packaging materials, manufacturing tools, raw materials, auxiliary materials [4].

During designing corporate logistics, account must be taken of the fact that the elements closer to the sales market has a decisive role over the preventive element of the process [5].

Today's entrepreneurs also have to face new challenges, such as:

- changing economic trends

- social, political problems, disasters

- changes in customer habits and supply chain strategies

- IT developments and revolutionary new, innovative technologies

- Changes in domestic and international legislation [6] 
Nowadays logistic has got important role in meat processing. Meat is a kind of fresh agricultural product. If it's not controlled properly, the quality of meat may change. In the process of storage and transportation the most important factor is the cold chain logistics [7].

On the Figure 1 we can see the common supply chain of the pork processing. In our work we analyse the some parts of the chain.

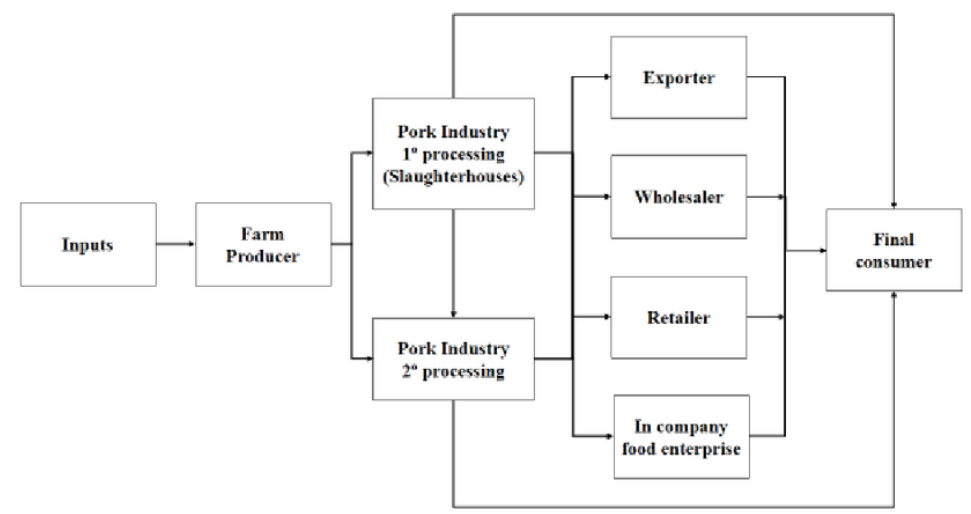

Figure 1. Pork supply chain scheme. Source [8]

Currently - we can declare - one of the symbol of the economical and financial success is the high-level controlling and logistic [9]

I indicate my aims as follows: A small of medium size slaughter enterprise has to be faced lots of problems both in logistics and other areas of the economy. I thought that I try to gain insights into the main challenges, tasks to be solved, by selecting a particular company. Recognizing the facts, I give a brief overview of these difficulties to readers. I try to find a solution to the problems, helping the selected enterprise.

\section{MATERIALS AND METHODS}

A personal interview was performed during the research with the General Manager of Ltd. During the interview, I was looking for answers to the questions of most important area, namely logistic, and if it was possible, for the right solutions for problems. Interview - with one of the owner as General Manager - was performed in Baja, at the company's premises.

The company has two different premises, first is at Csávoly where the pig slaughter takes place and the second is at Baja where the further processing is performed. The Company has 18 employees, 3 of them are leaders and 15 of them are physical workers. Besides the slaughterhouse and further-processing firm, the company has two butcher's shops at Baja. One of butcher's shop and the logo of company are presented in Fig. 2 and in Fig. 3.

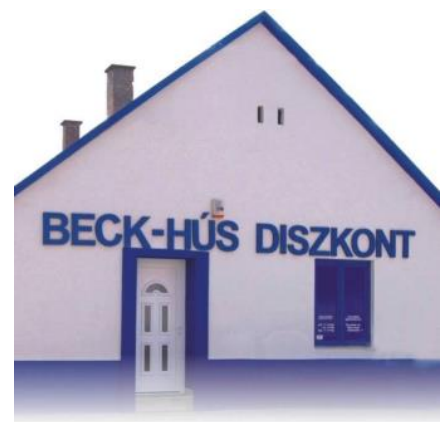

Figure 2. Butcher's shop of BECK-HÚS Ltd. Source: [10] 


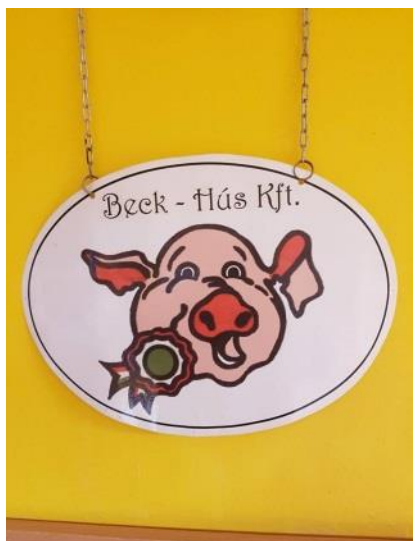

Figure 3. Logo of BECK-HÚS Ltd. Source: [11]

\section{RESULTS AND EVALUATION}

Based on the manager's statement, I could learn about the operation line, process steps of slaughter and further processing plants, furthermore the hypothetic and real capacity and the major yield indicators.

\subsection{Slaughter of pigs}

Usually, the weekly number of slaughtered pigs is about 90 heads. Exceptions, if any holiday (e.g. Christmas dinner) or special long weekend is approaching by any reason. In mentioned cases they cut by 10-12 head more than usual. About $80 \%$ of pigs to be slaughtered are bought from a big breeder farm, Green2000 Ltd., while the remaining $20 \%$ is coming, from small livestock farms. The real slaughter capacity is lower than that of hypothetic capacity because of weak solvency. Remarkable problem that the possible number of pigs per truck is 30 , but they has no rest area for pigs. So if they want to cut 90 pigs a week, it should mean 18 pigs (per truck) in every working day (5 days) resulting higher transport cost. They want to limit the transportation cost, so they cut pigs only on three days (but in case the slaughter firm does not work in two days). The unused cutting capacity cannot be called optimal. Weekly capacity mentioned by General Manager is about 200 pigs so the capacity utilization is about $45 \%$. Unfortunately, no solution has been found so far to this problem, possibly, they can organize the slaughter in leasing form, but of course it's only worth to deal in case of larger quantities and regular occasions.

Of the slaughtered animals, 30 are sold in the form of halves covered with skin and the remaining 60 are boned, cut to pork cuts and processed. Weekly yield of the most important primary products coming from 60 pigs is presented in Fig. 4. 


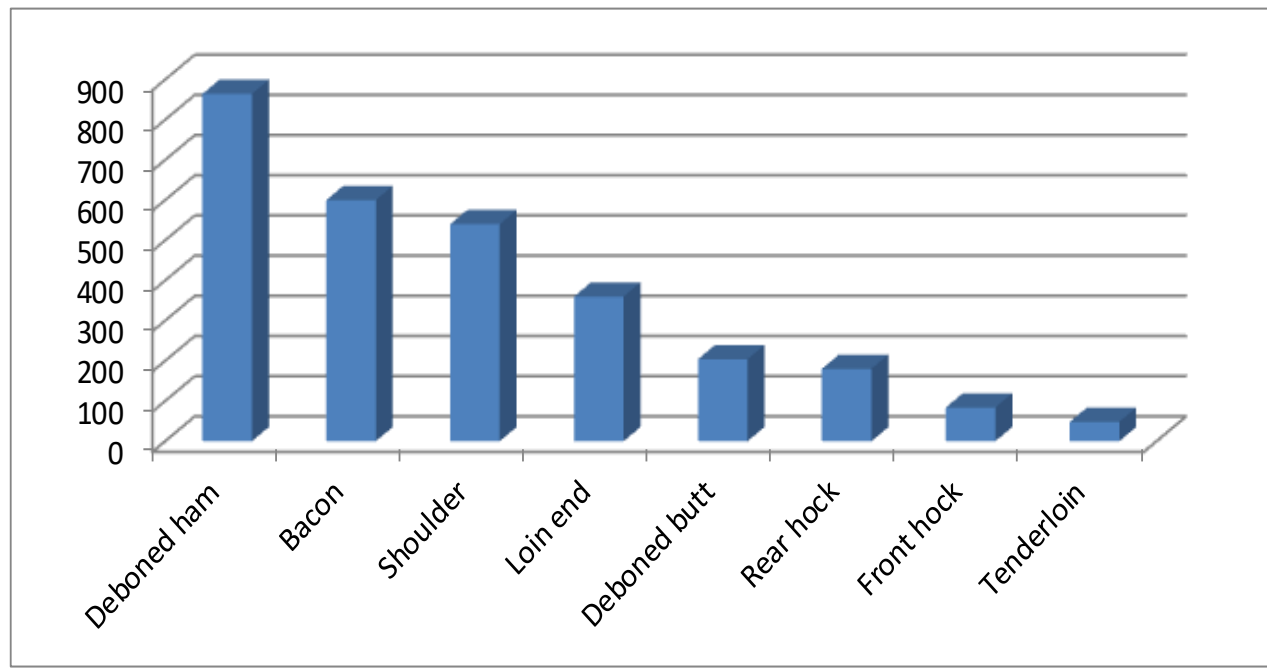

Figure 4. Weekly primary yield at BECK-HÚS Ltd. (Average; kg; Source: interview)

\subsection{Further processing}

Bigger part of presented primary yield is sold as carcass meat while $30-35 \%$ of all goes to further processing. We can mention that this ratio is also remarkably affected by the demand solvency.

Table 1. The ratio of different meat parts at BECK-HÚS Ltd. (\%) (Source: personal interview)

\begin{tabular}{|l|r|}
\hline Meat part's name & Percentage of processing \\
\hline Loin & 0 \\
\hline Tenderloin & 0 \\
\hline Butt & 10 \\
\hline Shoulder & 30 \\
\hline Ham & 60 \\
\hline Shoulder hock & 90 \\
\hline Lard & 100 \\
\hline
\end{tabular}

\subsection{Storage}

In case of meat products, the storage of them is a very sensitive problem in he HACCP system. This firm has got more storage room as follows:

a 100 square meters cooling room for carcasses, a 40 square meters cooling room for pickled products, a 20 square meter room for raw products and a 22 square meter end product cooling room.

Listing of different storage rooms pointed that the rules and directives in meat industry need many type of storage room, using different parameters in case of different type of products. The usage of storage capacity is about $90 \%$, actually it is not 100 percentage but better than that of the slaughter capacity usage. This high storage capacity usage explained by special reasons. First of all they hire the storage room for freezing storage of different meat parts, e.g. ear, feet freezing before Christmas holidays because Hungarian people use these parts to make a special gelled meat soup during winter season. Second case is the storage of cut raw meat for smoked, raw sausages (seasonally) and when a part of liver, lard or something else when they are not immediately processed. 


\subsection{Sales}

The most important customers: Pécsvárad with 20 pigs per week and a processing firm in Baja with 40 pigs, their own butcher's shops of BECK-HÚS Ltd and. some of restaurants, social houses and small entrepreneurs in Baja Region who purchase meat parts for further processing aims. 40-50 partners approx. are registered at BECK-HÚS Ltd. within $50 \mathrm{~km}$ radius area.

In the case of entrepreneurs, the recovery of payment obligations usually was a very important problem. Nowadays, almost every entrepreneurs pay with cash, based on agreements, so the company does not have a large stock of claims, fortunately. Some larger customers as hospitals, elderly houses, schools, etc. are exceptions, they pay with bank transfer.

\subsection{Suppliers}

Very important aspect is the group of suppliers. The biggest suppliers was mentioned related to the slaughter. Besides this the supply with different spices, packaging media and labels is very significant.

Spices are bought from PROFOOD and ALMI-Hungary Ltds. Pickleing salt is brought from the only domestic suppliers, namely from Kalle Hungaria Ltd. The most part of different covering media as natural and artificial casings are also bought from this company, but smaller suppliers are also exists. Packaging media are brought from Szigeti and Co. Ltd, Soltvadkert, but the vacuum foils from SÁGA poultry processing company. Cervus plus Ltd. has to be mentioned because it sometimes supplements the needs of lard and meat for BECK-HÚS Ltd.

The company has old - at least 5-10 years - and well-functioning connection with their suppliers. Company take the extra quality into the focus during the selection of suppliers. It was the most difficult in case of spices because there are many suppliers and they produce many-many different mixtures with very different sensory properties. Some years ago the company have found these suppliers and their spices mixtures so the sensory properties of their products are very well balanced; actually these are optimal mixtures for BECK-HÚS Ltd. The factory pays their debts via bank transfer using 30 days deadline despite the case of living animal. The deadline is two weeks for bigger pig farms and only one week for small breeders.

\section{CONSEQUENCES AND PROPOSALS}

Among challenges mentioned the Introduction, general manager mentioned only the changes of customer habits which in turn is related to the economic happenings. The extent of slaughter and further processing are determined by customer demand, solvency, incomes of people and the job opportunities, stand below the counts average in this region. From the above is clear that the slaughter capacity has hidden potential so it would be better to use the slaughter activity on the rest of two days in every week for example as slaughter in leasing form. Further possibility the increase of the sale amount of carcasses parallel with more slaughtered pigs involving new markets may be in distant regions. It needs the deep evaluation of costeffectiveness.

I heard from the General Manager that the company regularly publishes news about its sales actions in the local newspaper. It is good idea but this kind of advertising can only reach a certain audience, as many of them are thrown into the trash. In addition, it is recommended to use social media, in which different sales actions can be enhanced with impressive (appetizing) images, and the popularity of company can be enhanced with different games, etc. 


\section{REFERENCES}

[1] Halászné Sipos Erzsébet (1998): Logisztika Magyar Világ kiadó, Budapest

[2] Kovács Zoltán (2009): Logisztika, Jegyzet Pannon Egyetem

[3] Bányai Tamás (2014): A logisztika alapjai, Budapesti Gazdasági Főiskola

[4] Cselényi József - Illés Béla (2009): Logisztikai rendszerek I. Miskolci Egyetem

[5] Déri András - Kőhegyi Anita (szerk.) (2009): Logisztika az Európai Unióban és Magyarországon, Magyar Kereskedelmi és Iparkamara, Budapest

[6] Karmazin György - Ulecha Gergely (2015): A logisztika kihívásai a XXI. században Logisztikai trendek, 1. évfolyam 2. szám

[7] Li YaoXuan; Xue WenTing; Jin JiaLi; Hu JinLe; Qiu YiPeng; Tao Fei (2017):

Current status and development trend of cold chain logistics for pork of Hangzhou. Journal of Food Safety and Quality Vol.8 No.5 pp.1757-1762

[8] Joao G. M. Dos Reis - Sivanilza T. Machado - Rodrigo C. Santos - Irenilza De A. Naas - Rone V. Oliveira (2015: Financial losses in pork supply chain: A study of th epre-slaughter handling impacts Journal of the Brazilian Association of Agricultural Engineering. 35(1) pp 163-170 [9] József Gál - Éva Kmosko (2008): Connecting point of logistic, product-management and controlling at manufacturing companies. Analecta Technica Szegedinensia No 1. pp 31-37.

[10]

https://www.facebook.com/643812539156654/photos/a.643812999156608.1073741826.643812539156654 /643813002489941/?type=1\&theater

[11]

https://www.facebook.com/643812539156654/photos/a.644680919069816.1073741828.643812539156654 /644681842403057/?type=1\&theater (b) 